\title{
EVALUATION OF THE EFFECT OF PENTOBARBITONE ANAESTHESIA ON THE PLASMA POTASSIUM CONCENTRATION IN THE RABBIT AND THE DOG
}

\author{
W. Lane Robson, Colin E. Bayliss, Ross Feldman, Marc B. Goldstein, Ching-Bun Chen, \\ Robert M.A. Richardson, Bobby J. Stinebaugh, Siu-Cheung Tam and \\ Mitchell L. Halperin
}

\begin{abstract}
The purpose of these studies was to determine the reasons for the hypokalaemia observed in rabbits studied in our laboratory. The rabbits consumed standard rabbit chow which is rich in potassium and remained in potassium balance. Hypokalaemia was only observed following anaesthesia. A number of additional investigations were undertaken to clarify the mechanisms involved. The hypokalaemia could not be attributed to technical factors, alkalaemia, hyperinsulinaemia or hyperaldosteronism, but seemed to be a function of anaesthesia. This effect of pentobarbitone anaesthesia was not unique to the rabbit, as similar changes also occurred in the anaesthetized dog.

The findings reported in this paper have significant implications with respect to the interpretation of plasma potassium concentrations in anaesthetized subjects or animals.
\end{abstract}

Key Words: ANaesthesia, Plasma Potassium, Rabbit, Dog.

The PLASMA POTASSIUM concentration in normal anaesthetized rabbits in our laboratory is $3.2 \pm$ $0.1 \mathrm{mmol} / \mathrm{l}^{1}$, a value which is lower than that reported by most investigators ${ }^{2-8}$. Although the effect of anaesthetic agents on the plasma potassium concentration in different species has been reported previously, ${ }^{9}$ the mechanism for this change has not been studied in detail. These studies were undertaken to examine factors that might be responsible for the fall in plasma potassium concentration.

Pentobarbitone anaesthesia was found to lead to a significant fall in the plasma potassium concentration in both the rabbit and the dog. This anaesthesia-induced fall was associated with a significant increase in plasma renin activity and aldosterone concentration. No significant change occurred in the plasma insulin, glucose, sodium, chloride, phosphorus or blood $\left[\mathrm{H}^{+}\right]$. Depression of the plasma potassium concentration induced by pentobarbitone anaesthesia may have impor-

W. Lane Robson, M.D., F.R.C.P.(C); Colin E. Bayliss, M.D., F.R.C.S.(C); Ross Feldman, M.D.; Marc B. Goldstein, M.D., F.R.C.P.(C); Ching-Bun Chen, M.Sc.; Robert M.A. Richardson, M.D. F.R.C.P.(C); Bobby J. Stinebaugh, M.D., F.A.C.P.; Siu-Cheung Tam, Ph.D.; and Mitchell L. Halperin, M.D., F.R.C.P.(C).

All authors except Dr. Stinebaugh are affiliated with the Departments of Medicine and Physiology, University of Toronto, Toronto, Canada. Dr. Stinebaugh is with the Baylor College of Medicine, Houston, Texas.

Address correspondence to: Dr. M.L. Halperin, Lab. \# I, Research Wing, St. Michael's Hospital, 38 Shuter Street Annex, Toronto, Ontario MSB 1 A6.

Canad. Anaesth. Soc. J., vol. 28, no. 3, May 1981 tant implications to both physiological research and clinical medicine.

\section{Methods}

\section{Studies in Rabbits}

Male New Zealand white rabbits ( 2.5 to $3.5 \mathrm{~kg}$ ) were obtained from Reiman's Fur Ranch, St. Agatha, Ontario. Unless otherwise stated, rabbits were fed standard Purina Rabbit Chow and allowed free access to tap water.

Rabbits were premedicated with intramuscular chlorpromazine $(2.5 \%$ solution; $1 \mathrm{ml} / \mathrm{kg}$ body weight). Fifteen to thirty minutes later, anaesthesia was induced by a slow intravenous infusion of pentobarbitone ( $6 \%$ solution; $0.25 \mathrm{ml} / \mathrm{kg}$ body weight). Temperature was controlled by a thermal blanket. Incision sites were first infiltrated with one per cent lidocaine. Carotid artery specimens were obtained through a polyethylene catheter with an internal diameter of $0.34 \mathrm{~mm}$ and an outer diameter of $0.60 \mathrm{~mm}$. Blood for acidbase determinations was collected anaerobically whereas samples for electrolytes, metabolites and hormones were collected by free flow into heparinized tubes $(\sim 2 \mathrm{ml})$ and centrifuged immediately. Specimens with visual evidence of haemolysis were discarded.

\section{Evaluation of Collection Techniques}

In order to evaluate collection techniques, ten paired simultaneous samples were obtained from the ear and carotid arteries in five rabbits. In addition, ten simultaneous paired samples were 
drawn from the carotid artery by the standard catheter and by a 21 gauge needle. Eighteen blood samples were collected from the carotid artery catheter and one portion was allowed to clot and the other treated with heparin. Lastly, blood was collected into a beaker from 15 decapitated rabbits.

\section{Evaluation of the Effects of Anaesthesia}

In fifty-two rabbits the effects of anaesthesia were examined. Awake rabbits had a central ear artery site infiltrated with one per cent lidocainc and than a 22 gauge "Medicut" cannula was inserted. Control blood specimens were obtained from each rabbit. Blood specimens were collected thirty minutes following anaesthesia.

In a separate group of six rabbits the effect of intramuscular chlorpromazine was studied alone. Three control blood specimens were obtained from an ear artery before routine premedication with chlorpromazine. Thirty minutes later another three blood specimens were obtained.

DOCA $5 \mathrm{mg}$ (Percorten, Ciba Pharmaceuticals) was administered intramuscularly one to four hours before obtaining blood samples from the ear artery in five awake rabbits.

\section{Potassium Balance Studies}

Potassium balance studies were done on three rabbits which were kept in special metabolic collection cages, fed Purina Rabbit Chow $(31 \mathrm{mmol}$ $\mathrm{K}^{+} / 100 \mathrm{gm}$ ) and allowed free access to tap water. Urine and stool were collected every 24 hours for seven consecutive days. The amount of Rabbit Chow consumed in each 24 hour period was determined by weighing the food hampers each day. The effect of variation in dietary sodium and potassium on renal potassium excretion was examined in twelve rabbits. The rabbits were fasted but allowed access to tap water for eight days. For the final four days, they were divided into three groups: four rabbits each received water only, sodium chloride $(150 \mathrm{mmol} / \mathrm{l}), \mathrm{NaCl}$ $+\mathrm{KCl}(150 \mathrm{mmol} / \mathrm{l})$. On day eight, blood was collected from a central ear artery through a 21 gauge needle. A 24 hour urine collection was obtained from day seven to day eight.

\section{Tissue Potassium Measurements}

Cardiac muscle potassium was determined in six rabbits as previously described. ${ }^{10}$ Briefly, the animal was killed with an intravenous injection of $6 \mathrm{ml}$ of thiopentone $2 \%$ and the cardiac septum was excised within 2-3 minutes. A wet weight was obtained and the tissue was vacuum dried overnight in an oven. The specimen was pulverized and the tissue fat was extracted with petroleum ether. The specimen was oven dried and then extracted with nitric acid. The potassium content was measured, for this analysis only, using the unicam SP 1900 atomic absorption spectrophotometer and was reported as mmol $\mathrm{K}^{+} / \mathrm{kg}$ fat free dry weight.

\section{Studies in the Dog}

Seven male mongrel dogs ( 15 to $30 \mathrm{~kg}$ ) were housed individually and fed standard laboratory dog chow. Dogs were anaesthetized by slow intravenous infusion of pentobarbitone ( $6 \%$ solution, $0.25 \mathrm{ml} \cdot \mathrm{kg}^{-1}$ body wt). Specimens were obtained with a heparinized syringe from the brachial vein before and twenty minutes after the administration of pentobarbitone.

\section{Analytical Methods}

The blood and urine $\mathrm{pH}$ and $\mathrm{PCO}_{2}$ were measured immediately on a digital acid-base analyzer (model pH M72, Radiometer, Copenhagen, Denmark). Sodium and potassium were measured with a Radiometer flame photometer model FLM 2 using lithium as an internal standard. Chloride was measured with a Radiometer chloride titrator, model CMT 10 and inorganic phosphate was measured in the routine clinical chemistry laboratory. Insulin was measured by a radioimmunoassay system with a highly purified pork insulin standard as described by Marliss, et al. ${ }^{11}$ plasma renin activity as described by Cooper, et al.,2 plasma aldosterone as described by McKenzie, et al..$^{13}$ and plasma glucose by the glucose oxidase method on a Beckman glucose analyzer. The bicarbonate concentrations were calculated from the $\mathrm{pH}$ and $\mathrm{PCO}_{2}$ as previously described. ${ }^{1}$

\section{RESULTS}

Electrolyte Concentrations in Anaesthetized Rabbits: The mean plasma electrolyte values from anaesthetized rabbits are reported in Table I. The plasma potassium concentration ranged from 2.6 to $3.7 \mathrm{mmol} / \mathrm{l}$ with a mean value of $3.1 \pm$ $0.1 \mathrm{mmol} / \mathrm{l}$.

The mean plasma potassium concentrations were within $0.1 \mathrm{mmol} / \mathrm{l}$ when paired blood samples were obtained from the ear as opposed to the carotid artery or when drawn through a catheter or a 21 gauge needle. However, in 18 paired specimens obtained from the carotid artery by plastic cannula, the average serum potassium 


\section{TABLE I}

Plasma Electrolyte and Acid-Base Values in ANAESTHETIZED RABBITS

Blood was collected from a carotid artery in anaesthetized rabbits fed a normal diet. Results are reported as the mean \pm SEM. $\mathrm{n}=52$.

\begin{tabular}{lcl}
\hline \hline $\mathrm{Na}^{+} \mathrm{mmol} / \mathrm{l}$ & 144 & \pm 2 \\
$\mathrm{~K}^{+} \mathrm{mmol} / \mathrm{l}$ & $3.1 \pm 0.1$ \\
$\mathrm{Cl}^{-} \mathrm{mmol} / \mathrm{l}$ & 106 & \pm 2 \\
$\mathrm{HCO}_{3}{ }^{-} \mathrm{mmol} / \mathrm{l}$ & 22 & \pm 1 \\
{$\left[\mathrm{H}^{+}\right] \mathrm{nmol} / \mathrm{l}$} & $35.5 \pm 0.5$ \\
$\mathrm{PCO}_{2} \mathrm{kPa}(\mathrm{mmHg})$ & $4.39 \pm 0.133(33 \pm 1)$ \\
\hline
\end{tabular}

concentration was $4.3 \pm 0.1 \mathrm{mmol} / \mathrm{l}$ whereas the mean plasma value was $3.3 \pm 0.1 \mathrm{mmol} / \mathrm{l}$. The difference between these values was $1.0 \pm$ $0.1 \mathrm{mmol} / \mathrm{l}, \mathrm{p}<0.05$. No other differences were noted. In addition, when blood was collected into a beaker from 15 decapitated rabbits, the mean serum potassium concentration was $4.8 \pm 0.2$ $\mathrm{mmol} / \mathrm{l}$, a value significantly higher than the serum collected from the carotid artery by plastic cannula.

Balance Studies in Rabbits: Rabbits ingested $35 \pm 1 \mathrm{mmol}$ of potassium per day over twentyone days of observation. During this period their mean daily urinary excretion of potassium was 30 $\pm 1 \mathrm{mmol} / \mathrm{l}$ per $120 \mathrm{mg}$ creatinine and their mean daily faecal excretion of potassium was $3 \mathrm{mmol}$.

The effect of variation in dietary potassium and sodium on urine potassium excretion was analyzed in twelve rabbits (Table II). When potassium was removed from the diet, potassium excretion in the urine fell virtually to zero indicating normal renal mechanisms to conserve potassium in the presence of sodium in the urine. When sodium and potassium were both added to the drinking water, the rabbit increased urinary potassium excretion and maintained a plasma potassium of $3.2 \mathrm{mmol} / \mathrm{l}$.

Tissue Potassium Content: In six rabbits, intracellular potassium was measured in cardiac muscle and found to be $427 \pm 13 \mathrm{mmol} / \mathrm{kg}$ FFDW.

\section{Effect of Pentobarbitone Anaesthesia on Plasma Potassium Concentration and Factors which may Influence this Parameter}

The plasma potassium concentration fell significantly following pentobarbitone anaesthesia in both the rabbit and dog (Tables III and IV). Although there were changes in acid base balance, these were small and not consistent in both dogs and rabbits. There was a significant increase in plasma renin activity and aldosterone concentration in the rabbit (Table III) and a fall in the plasma insulin concentration noted in the dog (Table IV) with anaesthesia. There were no significant changes noted in plasma anion-gap, glucose and phosphorus observed in either the rabbit or the dog.

\section{Effect of Intramuscular Chlorpromazine on}

Plasma Potassium Concentration

There was no significent difference in plasma potassium before $(3.9 \pm 0.1 \mathrm{mmol} / \mathrm{l})$ or $30 \mathrm{~min}$ utes after intramuscular chlorpromazine (3.9 \pm $0.1 \mathrm{mmol} / \mathrm{l})$.

TABLE II

Effect of Potassium Intake on Pottassium Balance, Plasma Electrolytes and AcidBase Parameters and Urine Potassium Excretion

Twelve rabbits wre fasted for eight days. On day eight, 24 hour urine collections were obtained. Four rabbits reach received: water only, $\mathrm{NaCl}(150 \mathrm{mmol} / \mathrm{l})$, or $\mathrm{NaCl}(150 \mathrm{mmol} / \mathrm{l})$ and $\mathrm{KCl}(150 \mathrm{mmol} / \mathrm{l})$ in the drinking water over the last four days. Results are reported as the mean \pm SEM. Plasma values were obtained from anaesthetized rabbits

\begin{tabular}{|c|c|c|c|c|c|}
\hline & \multicolumn{5}{|c|}{ Intake } \\
\hline & & $\mathrm{O}$ & & $\mathrm{aCl}$ & $\mathrm{NaCl}+\mathrm{KCl}$ \\
\hline $\begin{array}{l}\text { Urine } \\
\mathrm{Na}^{+} \mathrm{mmol} / \text { day } \\
\mathrm{K}^{+} \mathrm{mmol} / \text { day }\end{array}$ & $\begin{array}{l}1 \\
2\end{array}$ & $\begin{array}{l} \pm 1 \\
\pm 1\end{array}$ & $\begin{array}{r}39 \\
1\end{array}$ & $\begin{array}{l} \pm 13 \\
\pm 1\end{array}$ & $\begin{array}{ll}110 & \pm 4 \\
121 & \pm 11\end{array}$ \\
\hline $\begin{array}{l}\text { Plasma } \\
\mathrm{Na}^{+} \mathrm{mmol} / \mathrm{l} \\
\mathrm{K}^{+} \mathrm{mmol} / 1 \\
\mathrm{Cl}^{-} \mathrm{mmol} / \mathrm{l} \\
\mathrm{HCO}_{3}^{-} \mathrm{mmol} / \mathrm{l} \\
{\left[\mathrm{H}^{+}\right] \mathrm{nmol} / 1} \\
\mathrm{PCO}_{2} \mathrm{kPa}(\mathrm{mmHg})\end{array}$ & $\begin{array}{l}137 \\
2.8 \\
103 \\
23 \\
41.5 \\
5.14\end{array}$ & $\begin{array}{l} \pm 2 \\
\pm 0.1 \\
\pm 4 \\
\pm 1 \\
\pm 1.5 \\
\pm 0.4(39 \pm 3)\end{array}$ & $\begin{array}{l}137 \\
3.0 \\
103 \\
22^{*} \\
36.2 \\
4.52\end{array}$ & $\begin{array}{l} \pm 3 \\
\pm 0.1 \\
\pm 2 \\
\pm \quad 1.3 \\
(34)^{*}\end{array}$ & $\begin{aligned} & 142 \pm 1 \\
& 3.2 \pm 0.1 \\
& \text { NA } \\
& 21 \quad \pm 1 \\
& 41.1 \pm 1.0 \\
& 4.79 \pm 0.26(36 \pm 2)\end{aligned}$ \\
\hline
\end{tabular}

NA, Not assayed.

* Single determination only. 
TABLE III

Effect of anaesthesia on Plasma Electrolytes, Metabolites, Acid Base Parameters and Hormone LeVels in the EAR ARTERy OF THE RABBit

Results are reported as the mean \pm SEM. The number of animals appears in parentheses.

\begin{tabular}{|c|c|c|c|c|c|}
\hline & & & & Awake (15) & Anaesthetized (15) \\
\hline $\mathrm{Na}^{+}$ & $\mathrm{mmol} / \mathrm{l}$ & & 147 & \pm 1 & $146 \pm 1$ \\
\hline $\mathbf{K}^{+}$ & $\mathrm{mmol} / \mathrm{l}$ & & 4.0 & \pm 0.1 & $3.5 \pm 0.1$ \\
\hline $\mathrm{Cl}^{-}$ & $\mathrm{mmol} / \mathrm{l}$ & & 110 & \pm 1 & $109 \pm 1$ \\
\hline $\mathrm{HCO}_{3}^{-}$ & $\mathrm{mmol} / \mathrm{l}$ & & 23 & $\pm I$ & $21 \pm 1$ \\
\hline$\left[\mathrm{H}^{+}\right]$ & $\mathrm{nmol} / 1$ & & 36.9 & \pm 0.6 & $36.7 \pm 0.9$ \\
\hline $\mathrm{PCO}_{2}$ & $\mathrm{kPa}(\mathrm{mmHg})$ & & 4.66 & $6 \pm 0.133(35 \pm 1)$ & $4.12 \pm 0.133(31 \pm 1)$ \\
\hline Phosphorus & $\mathrm{mM}$ & $n=6$ & 2.0 & \pm 0.1 & $2.0 \pm 0.1$ \\
\hline Aldosterone & $\mathrm{ng} / \mathrm{dl}$ & $n=6$ & 28 & \pm 2 & $38 \pm 3^{*}$ \\
\hline Renin Activity ${ }^{1}$ & & $\mathrm{n}=6$ & 16 & \pm 2 & $\pm 22^{*}$ \\
\hline Glucose & $\mathrm{mg} / \mathrm{dl}$ & $\mathrm{n}=6$ & 128 & \pm 2 & \pm 9 \\
\hline
\end{tabular}

*Indicates $\mathrm{p}<0.05$

'Renin activity is expressed as $\mathrm{ng}$ angiotensin generated $/ \mathrm{ml} \mathrm{plasma} / \mathrm{hr}$.

TABLE IV

Effect of anaesthesia on Plasma Electrolytes, Metabolites, Acid-Base PARAMETERS AND HORMONES IN THE DOG

Blood was collected from a brachial vein into a heparinized syringe before and 20 minutes after pentobarbitone anaesthesia. Results are reported as mean $\pm S E M$ for seven dogs

\begin{tabular}{|c|c|c|c|c|c|}
\hline & & \multicolumn{4}{|c|}{ Pentobarbitone } \\
\hline & & \multicolumn{2}{|r|}{ Before } & \multicolumn{2}{|r|}{ After } \\
\hline $\mathrm{Na}^{+}$ & $\mathrm{mmol} / \mathrm{l}$ & 147 & \pm 5 & 146 & \pm 5 \\
\hline $\mathrm{K}^{+}$ & $\mathrm{mmol} / \mathrm{I}$ & 4.5 & \pm 0.1 & 3.8 & $\pm 0.1^{*}$ \\
\hline $\mathrm{Cl}^{-}$ & $\mathrm{mmol} / \mathrm{l}$ & 112 & \pm 2 & 113 & \pm 2 \\
\hline $\mathrm{HCO}_{3}^{-}$ & $\mathrm{mmol} / \mathrm{l}$ & 24 & \pm 2 & 21 & \pm 3 \\
\hline$\left[\mathrm{H}^{+}\right]$ & $\mathrm{mmol} / \mathrm{l}$ & 50.4 & \pm 2.9 & 51.9 & \pm 3.1 \\
\hline $\mathrm{PCO}_{2}$ & $\mathrm{kPa}(\mathrm{mmHg})$ & 6.52 & $\pm 0(49 \pm 0)$ & 5.72 & $\pm 0.4(43 \pm 3)$ \\
\hline Insulin & $\mathrm{ng} / \mathrm{ml}$ & 0.63 & \pm 0.09 & 0.40 & \pm 0.10 \\
\hline Glucose & $\mathrm{mg} / \mathrm{dl}$ & 77 & \pm 3 & 81 & \pm 4 \\
\hline Phosphorus & $\mathrm{mM}$ & 1.8 & \pm 0.1 & 1.7 & \pm 0.1 \\
\hline
\end{tabular}

$* \mathrm{p}<0.01$

Effect of DOCA on Plasma Potassium Concentration in Awake Rabbits

In order to evaluate possible acute effects of mineralocorticoids, plasma potassium concentration was determined in blood from the central ear artery of awake rabbits which had received $5 \mathrm{mg}$ of DOCA in the preceding one to four hours and was found to $4.0 \pm 0.1 \mathrm{mmol} / \mathrm{l}(\mathrm{n}=5)$. This value was similar to that from awake rabbits which had not received DOCA (Table III).

\section{Discussion}

\section{General Comments}

We have previously reported that the plasma potassium concentration in the anaesthetized rabbit is $3.2 \pm 0.1 \mathrm{mmol} / l^{1}$, a value that is significantly lower than that reported in most studies in the literature ${ }^{2-8}$. To determine the reasons for this discrepancy, we have evaluated several technical factors that might be responsible for spurious changes. Our results demonstrate that a number of these factors can lead to alterations in reported values for potassium concentration. For example, the potassium concentration was higher in serum than in plasma whether the blood was obtained by decapitation or through a cannula. Whether this difference is due to release of potassium from red cells or platelets was not determined. The plasma potassium concentration is also higher in venous than in arterial blood. ${ }^{14}$ Therefore, it is clear that 
attention to these technical details is important when studying potassium homeostasis and when comparing results from different laboratories. Nevertheless, when all the above were taken into consideration, the plasma potassium concentration reported in these studies was lower than that reported from most other laboratories.

\section{Potassium Balance in the Rabbit}

In order to document that the population of rabbits studied was behaving in a physiologically appropriate manner and to exclude potassium deficiency, we did balance studies on rabbits which ate their normal diet and subjected other rabbits to a potassium restricted diet. The results of these studies revealed that the animals behaved normally; that is they were in potassium balance, conserved potassium when on a low potassium diet even when distal sodium delivery was markedly increased. Furthermore, analysis of cardiac muscle potassium content revealed normal values. ${ }^{6}$

\section{Effect of Pentobarbitone Anaesthesia on \\ Plasma Potassium Concentration}

Since all forms of anaesthesia have been shown to affect cation transport across the cell membrane, ${ }^{15,16}$ we considered the possibility that the low plasma potassium concentration in the rabbit might be the result of anaesthesia. Our results demonstrated that pentobarbitone anaesthesia resulted in a fall of the plasma potassium concentration of $0.4 \pm 0.1 \mathrm{mmol} / 1$ (Table III). This fall did not occur following premedication with chlorpromazine $\left(\mathrm{K}^{+}=0.0 \pm 0.1 \mathrm{mmol} / \mathrm{l}, \mathrm{n}=6\right)$. There was no measurable urine flow in the rabbits during the experimental period. In order to demonstrate that this effect of pentobarbitone anaesthesia was not unique to the rabbit, similar studies were done in the dog. As with the rabbit, plasma potassium fell $0.7 \pm 0.1 \mathrm{mmol} / 1$ following anaesthesia (Table IV).

To define further the mechanisms that might bring about the fall in plasma potassium concentration, we measured various factors which affect potassium distribution that may have been altered with anaesthesia. Potassium distribution is influenced by changes in hydrogen or anion concentrations. No consistent changes in those factors occurred with anaesthesia in either the rabbit or the dog (Tables III and IV).

We then investigated the effects of anaesthesia on insulin and glucose concentrations in the dog. An increase in insulin concentration has been shown to cause a potassium shift into the intracel. lular space by a mechanism which is, in part. independent of glucose metabolism. ${ }^{17-22}$ How. ever, in the dog, the plasma insulin concentration fell with anaesthesia and there was no change in plasma glucose concentration (Table IV). These results rule out an action of insulin in the pathogenesis of the potassium shift.

We also evaluated the effects of anaesthesia on plasma renin activity and plasma aldosterone concentration in the rabbit. It has been suggested that aldosterone causes a transfer of potassium into the intracellular space s.29 $^{23-29}$ but this is not universally accepted. Our results demonstrate that there was a significant increase in plasmi aldosterone concentration and plasma renin activity after pentobarbitone anaesthesia (Table III). However, we consider it unlikely that an increase in aldosterone concentration is responsible for the hypokalaemia induced by anaesthesia, as the plasma potassium concentration was not altered by the acute administration of pharmacological doses of DOCA to awake rabbits.

Catecholamines have been shown to alter potassium distribution, with $\beta$-adrenergic stimulation leading to hypokalaemia. ${ }^{29-33}$ However, the plasma catecholamine levels have been shown to decrease during anaesthesia in the dog and in the rat. ${ }^{34}$ Hence, elevated plasma catecholamines could not be the total explanation for the hypokalaemia following anaesthesia.

Several clinical studies have been done to evaluate the effects of anaesthesia on the plasma potassium concentration. ${ }^{35-38}$ In general anaesthesia resulted in a fall in the plasma potassiurn concentration, but parameters including hormone levels, acid-base and electrolyte changes were not reported in all studies. Hence, the mechanisms responsible for the fall in the plasma potassium concentration could not be evaluated in these clinical studies.

In summary, rabbits and dogs were observed to have a lower plasma potassium concentration following pentobarbitone anaesthesia. The mechanism of this effect is unknown. It does not seem to operate through simple alterations in the levels of insulin, aldosterone or catecholamines. It may reflect a direct effect of anaesthetics reducing potassium efflux from cells. This observation may have significant implications. The results from the literature tend to support these observations in that higher values for plasma potassium are reported when investigators use awake rabbits. ${ }^{3,4}$ 


\section{ACKNOWLEDGEMENTS}

The authors are very grateful to R. Baffour, B. Gardner, P. Keane, E. Marliss, D. Osmond, M. Silverman, J. Turner, R. Wald and M. Waxman for expert help and advice.

\section{REFERENCES}

1. Giammarco, R.A., Goldstein, M.B., Halperin, J.S., et al. Collecting duct hydrogen ion secretion in the rabbit: role of potassium. J. Lab. Clin. Med. 91: 948 (1978).

2. Braverman, B. \& David, J.O. Adrenal steroid secretion in the rabbit: $\mathrm{Na}$ depletion, angiotensin II and ACTH. Am. J. Physiol. 225: 1306 (1973).

3. Dawborn, J.K. \& Watson, L. Effect of prolonged administration of aldosterone on potassium and magnesium metabolism in the rabbit. Med. J. Aust. 2: 304 (1968).

4. Johnson, J.A., David, J.O. \& Braverman, B. Role of angiotensin II in experimental renal hypertension in the rabbit. Am. J. Physiol. 228: 11 (1975).

5. Lohmeimer, T.E., Dayid, J.O., Janson, R.C., et $a l$. Renin angiotensin aldosterone system in rabbits with thoracic caval constriction. Am. J. Physiol. 232: F559 (1977).

6. Poole-Wilson, P.A. \& Cameron, I.R. Intracellular $\mathrm{pH}$ and $\mathrm{K}^{+}$of cardiac and skeletal muscle in acidosis and alkalosis. Am. J. Physiol. 229: 1305 (1975).

7. Schwartz, G.J. \& Burg, M. Mineralocorticoid effects on cation transport by $\mathrm{CCT}$ in vitro. Am. $\mathrm{J}$. Physiol. 235(6): F576 (1978).

8. Torres, V.E., Strong, C.G., Romero, J.C., et al. Changes in plasma renin substrate, plasma and renal renin and plasma osmolality during glycerol induced ARF in rabbits. Mayo Clin. Proc. 50: 111 (1975).

9. STEWART, J.M. Effect of barbiturate anaesthesia on potassium metabolism of the rabbit and dog. Am. J. Physiol. 163: 622 (1930).

10. Flear, C.T.G. \& Florence, I. A rapid and micro method for the analysis of skeletal muscle for water, sodium potassium, chloride and fat. Clin. Chim. Acta 6: 129 (1961).

11. Marliss, E.B., Murray, F.T. \& Nakhooda, A.F. The metabolic response to hypocaloric protein diets in obese man. J. Clin. Invest. $62: 468$ (1978).

12. Copper, R.M., Murray, G.E. \& Osmond, D.H. Trypsin-induced activation of renin precursor in plasma of normal and anephric man. Circ. Res. (supple. 1) 40: 1, (May, 1977).

13. McKenzie, J.K. \& Clements, J.A. Simplified radioimmunoassay for serum aldosterone utilizing increased antibody specificity. J. Clin. Endo. \& Metab. 38: 622 (1974).

14. Ward, C.F., Arkin, D.B., Benumof, J.L., et al. Arterial versus venous potassium: clinical implications. Crit. Care Med. 6: 335 (1978).

15. Seeman, P. Membrane actions of anaesthetics and tranquilizers. Pharmacol. Rev. 24: 583 (1972).

16. Seeman, P., Kwant, W.O., Goldberg, M., et al.
The effects of ethanol and chlorpromazine on the passive membrane permeability to $\mathrm{Na}^{+}$. Biochim. Biophys. Acta 241: 349 (1971).

17. ZiERLER, K.L. Effect of insulin on membrane potential and potassium content of rat muscle. Am. J. Physiol. 197: 515 (1959).

18. ZierLer, K.L. Possible mechanisms of insulin action on membrane potential and ion fluxes. Am. J. Med. 40:735 (1966).

19. Pettit, G.W. \& Vick, R.L. Contribution of pancreatic insulin to extrarenal potassium homeostasis: a two-compartment model. Am. J. Physiol. 226: 319 (1974).

20. Perez, G.O., Lespier, L., Knowles, R. et al. Potassium homeostasis in chronic diabetes mellitus. Arch. Int. Med. 137: 1018(1977).

21. Hiatt, N., Morgenster, L., Davidson, M.B..et al. Role of insulin in the transfer of infused potassium to tissue. Horm. Metab. Res. 5: 84 (1973).

22. Hiatt, N., Yamakawa, T. \& Davidson, M.B Necessity for insulin in transfer of excess infused $K$ to intracellular fluid. Metabolism 23: 43 (1974),

23. Alexander, E.Q. \& Levinsky, N.G. An extrarenal mechanism of potassium adaptation. J. Clin. Invest. 47: 740 (1968).

24. ADLER, S. An extrarenal action of aldosterone on mammalian skeletal muscle. Am. J. Physiol. 218: $616(1970)$.

25. Silva, P., Brown, R.S. \& Eptstein, F.S. Adaptation to potassium. Kidney Int. 11:466 (1977).

26. Cox, M., Sterns, R.H. \& Singer, I. The defense against hyperkalemia: the roles of insulin and aldosterone. New Eng. J. Med. 299: 525 (1978).

27. Goldfarb, S., Strunk, B., Singer, I., et al. Paradoxical glucose-induced hyperkalemia. Am. J. Med. 59: 744 (November 1975).

28. Goldfarb, S., Cox, M., Singer, I., et al. Acute hyperkalemia induced by hyperglycemia: hormonal mechanisms. Ann. Int. Med. 84:426 (1976).

29. Ammon, R.A., MaY, W.S. \& Nightingale, S.D. Glucose-induced hyperkalemia with normal aldosterone levels. Ann. Int. Med. 89 : 349 (1978)

30. ToDD, E.P. \& VICK, R.L.: Kalemotropic effect of epinephrine: analysis with adrenergic agonists and antagonists. Am. J. Physiol. 220: 1964 (1971).

31. Vick, R.L., Todd, E.P. \& LUEdKe, D.W. Epinephrine-induced hypokalemia: relation to liver and skeletal muscle. J. Pharmacol. \& Exp. Therap. 181: 139 (1972)

32. D'Silva, J.L. The action of adrenaline on serum potassium. J. Physiol. 82: 393 (1934).

33. D'Silya, J.L. The action of adrenaline on serum potassium. J. Physiol. 86: 219 (1936)

34. RoIzen, M.F., Moss, J., Henry, D.P., et al. Effects of halothane on plasma catecholamines. Anesthesiology 41:432 (1974).

35. RobBins, B.H. \& PATT, H.A. Ether anesthesia changes in the serum potassium content during and following anesthesia. J. Pharmacol. \& Therap. 56-7: 205 (1936).

36. Dobkin, A.B., LeE, P.K.Y., Byles, P.H., et al Neuroleptanalgesics: A comparison of the cardiovascular, respiratory and metabolic effects of innovan and thiopentone plus methotrimeprazine. Br. J. Anaesth. 35: 694 (1963) 
37. LIST, W.F. Serum potassium changes during induction of anaesthesia. Br. J. Anaesth. 39: 480 (1967).
38. Stovner, J., Endresen, R. \& Bjelke, E. Suxamethonium hyperkalaemia with different induction agents. Acta Anaesth. Scand. 16: 46(1972).

\section{RÉSUMÉ}

Le but de cette étude était de déterminer la cause de l'hypokaliémie observée à la suite de l'anesthésie des lapins de laboratoire. Ces lapins consommaient une moulée standard à lapins riche en potassium et capable de maintenir en balance cet électrolyte. Plusieurs investigations supplémentaires furent entreprises pour élucider les mécanismes responsables. La baisse de la kaliémie ne put être attribuée à des facteurs techniques, à l'alcalémie, l'hyperinsulinémie ou l'hyperaldostéronisme mais semblait bien être une conséquence de l'anesthésie au pentobarbitone. Cet effet ne survenait pas uniquement sur les lapins mais aussi sur les chiens anesthésiés.

Les données rapportées dans ce travail peuvent modifier significativement l'interprétation des résultats d'analyse de la kaliémie plasmatique chez les patients et les animaux anesthésiés. 